\title{
DOWNHOLE SEISMIC REFRACTION SURVEY OF WEATHERED LAYER CHARACTERISTICS IN ESCRAVOS, NIGERIA
}

\begin{abstract}
Ochuko Anomohanran
Department of Physics, Faculty of Science, Delta State University, Abraka, Delta State, Nigeria

Received 2013-12-03; Revised 2013-12-05; Accepted 2013-12-30

ABSTRACT

The problem of datum correction in seismic surveys and the failures associated with civil engineering structures with specific reference to roads and buildings has been attributed to lack of understanding of the soil structure among others. This is why this survey on downhole seismic refraction was conducted from nine borehole locations in Escravos, Nigeria to determine the weathered layer characteristics of the area. In carrying out this study, the McSeis $160 \mathrm{MX}$ instrument was employed in recording data obtained from a set of hydrophones arranged in a definite manner in each of the boreholes. The data were analysed graphically by using the seismic refraction interpretation techniques. Results of interpretation indicate that the velocity of the weathered layer ranged between 454 and $533 \mathrm{~m} \mathrm{sec}^{-1}$ with an average value of $495 \mathrm{~m} \mathrm{sec}^{-1}$. The results also revealed that the depth of the weathered layer ranged between 2.91 and $4.41 \mathrm{~m}$ with an average value of $3.68 \mathrm{~m}$. Analysis of the results revealed that the depth and velocity of the weathered layer increased downward towards the southern part of the study area. This is an indication that the weathered layer sloped downward to the south. It is recommended that shots for seismic survey should be located at a depth of 4.41 $\mathrm{m}$ to eliminate the effects associated with the low velocity layer. It is also recommended that construction of heavy buildings and roads especially bridges should have their foundations laid to a depth of $4.41 \mathrm{~m}$ to enable the infrastructure sit on the consolidated layer.
\end{abstract}

Keywords: Downhole, Weathered Layer, Hydrophones, Seismic Wave, Escravos

\section{INTRODUCTION}

The weathered layer of bedrock is described as the shallow surface layer composed of unconsolidated materials such as soil, sand and gravel. It is heterogeneous in composition and is characterised by low seismic velocity which account for the delay experienced in travel time of the seismic wave (Uko et al., 2012; Kolawole et al., 2012; Kar and Berenjian, 2013). The weathered layer is also characterised by high porosity, lack of cementation, low pressure and low bulk modulus. All of these properties account for the very low compressional and shear wave velocities observed in the layer. The base of the weathered layer can be referred to as the interface between the weathered layer and consolidated layer.

Seismic method of geophysical investigation is usually used to investigate the earth stratigraphy, site geology and rock quality because of its high resolution and accuracy (Abdul-Nafiu et al., 2013; Anomohanran, 2013a). At relatively smaller scale, this method is also applied to the search for groundwater as well as in environmental and civil engineering investigations (Anomohanran, 2013b; 2013c; Asry et al., 2012). This method is known to provide detailed information about the subsurface layers including the geomechanical properties of the formations (Chiemeke and Aboh, 2012). The techniques employed in the determination of geological structure and rock velocities are either refracting or reflecting waves off the boundaries between rock units having different seismic characteristics.

The seismic refraction under which downhole survey falls is used to investigate the properties of the 
subsurface. This is done by generating arrival time and offset distance information to determine the path and velocity of the elastic disturbance in the ground. The theory is that the rays are refracted across layer boundaries where there is a difference in the properties of the formations. The critically refracted signal travels down through the different layers before returning back to the surface to be successfully detected by the line of geophones (Anomohanran, 2012).

Uphole and downhole seismic refraction studies are the most important and commonly used techniques for studying the features of the low velocity layer (Alaminiokuma and Amonieah, 2012). These two techniques are useful in delineating the near surface velocities, depths and thicknesses of the layers in the vertical direction (Alaminiokuma and Amonieah, 2012; Gabr et al., 2012). The velocity data obtained from these techniques are used in determining the geology and seismic response of a particular site. The raw data acquired from a downhole study are the travel times of compressional and shear waves from the source to the geophones and the distance between the source and geophones (Ayolabi et al., 2009).

In the case of a downhole survey, a seismic source is used to generate a seismic signal at the ground surface offset horizontally from the top of a cased borehole while downhole receivers are used to detect the arrival of the seismic wave train. The receivers are usually placed at selected test depths in a borehole. The method involves connecting the source and the receivers to a data recording system that records the response of the downhole receivers when a seismic signal is initiated.

The seismic signal could be created by explosives, hammer, weight drop, or some other equivalent methods for sending impulsive energy into the ground (Igboekwe and Ohaegbuchu, 2011; Asry et al., 2012; Anomohanran, 2013a). Detectors which are laid out at regular intervals are used to detect the first arrival of the energy and measure its time. The records are plotted in time-distance graphs from which the velocities of the different layers and their depths are estimated.

Geophysicists use these weathered layer parameters in the design of receiver source arrays for field filtering purposes (Uko et al., 2012). These parameters are used in the analysis of soil behaviour under static and dynamic loads. The elastic constants obtained are input variables into the models defining the different states of deformations such as elastic, elasto-plastic and failure
(Varughese et al., 2011; Chiemeke and Aboh, 2012). Another important use of estimated shear wave velocities in geotechnical design is in the liquefaction assessment of soils (Teachavorasinskun et al., 2009).

The area under study is an oil rich location with a lot of seismic surveys and engineering constructions going on in the area. It is therefore important to understand the characteristics of the soil structure hence this study to determine the weathering layer characteristics becomes important.

\section{MATERIALS AND METHODS}

\subsection{Location and Geology of the Area}

The area under investigation named Escravos is located in the Niger Delta Basin and situated along longitude 5.55 and $5.59^{\circ}$ east and latitude 5.61 and $5.63^{\circ}$ north (Fig. 1). The area is characterised by an upward regressive sequence of tertiary sediments that progressed over passive continental sediments. Three major sedimentary cycles have occurred in the Niger Delta structural basin since the early Cretaceous. The subsurface stratigraphic units associated with the cycles are, the Benin, the Agbada and the Akata formations (Ofomola, 2011; Akpoborie et al., 2011). The Benin formation is about $1800 \mathrm{~m}$ deep and consists essentially of loose and unconsolidated sands. The sand constitutes about $90 \%$ while the shale/clay makes up only about $10 \%$. The sand in the Benin formation is made up of fine to coarse grain and gravel and are also poorly sorted, sub-angular to well-rounded and contains lignite streaks and wood rubble (Akpoborie et al., 2011). The Agbada formation underlies the Benin formation and it consists of intercalations of shale and sandstone lithologies. The Agbada formation is the main reservoir rock of the basin while its shale layers as well as those of the underlying formation serve as the source rocks (Kolawole et al., 2012). The Akata formation is significantly made up of shale with sand constituting only about $10 \%$. The shale is understood to be over pressured and under-compacted. It is rich in hydrocarbon and constitutes the source rock for hydrocarbon (Ofomola, 2011).

\subsection{Field Operation}

This study to investigate the velocity and depth of the weathered layer in Escravos was carried out at nine survey points as shown in Fig. 2. In each of the survey points labelled A, B, C, D, E, F, G, H and I, a borehole was drilled to a depth of about 62 metres. Plastic casings made up of 6 inch PVC pipe were installed in the hole to prevent it from collapsing. 


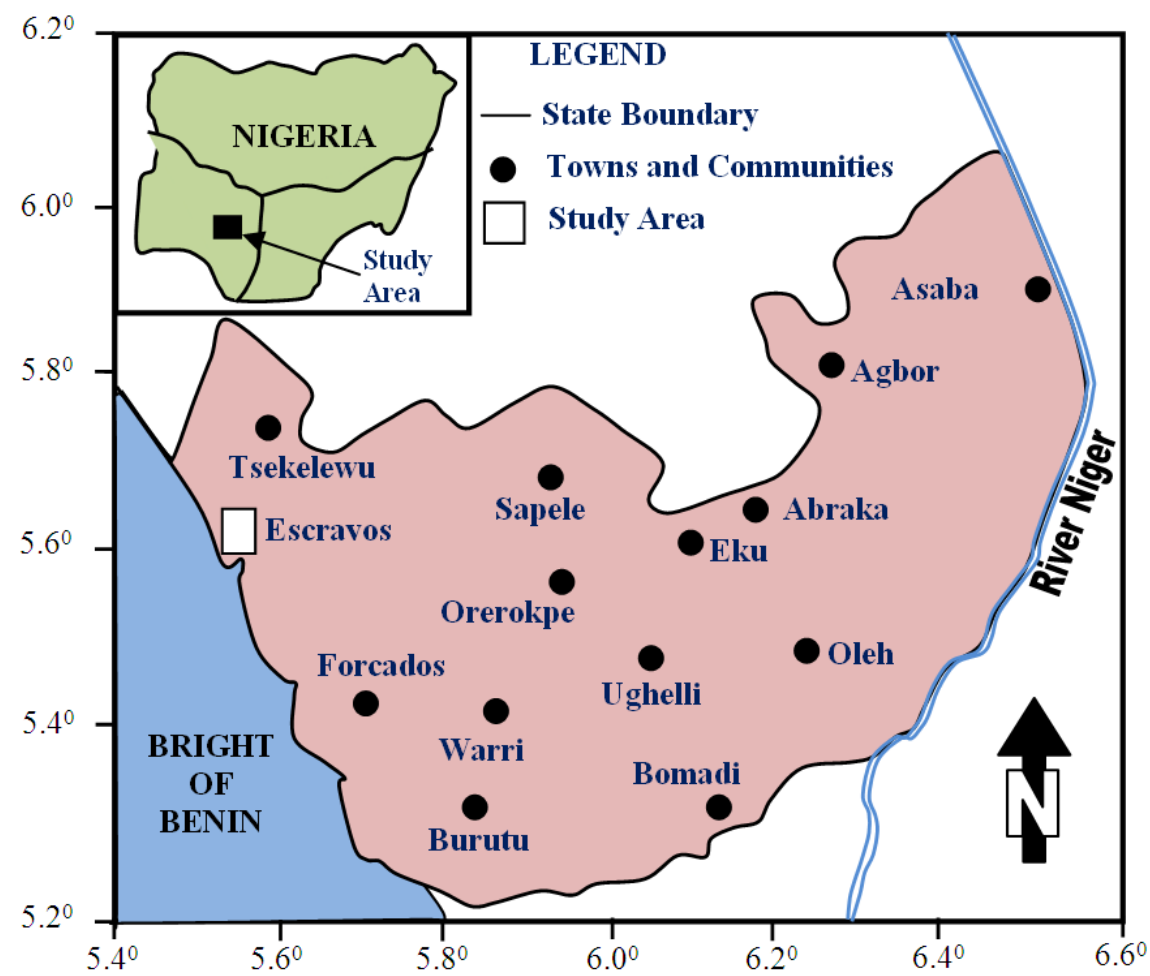

Fig. 1. Map of Delta State, Nigeria showing the study area

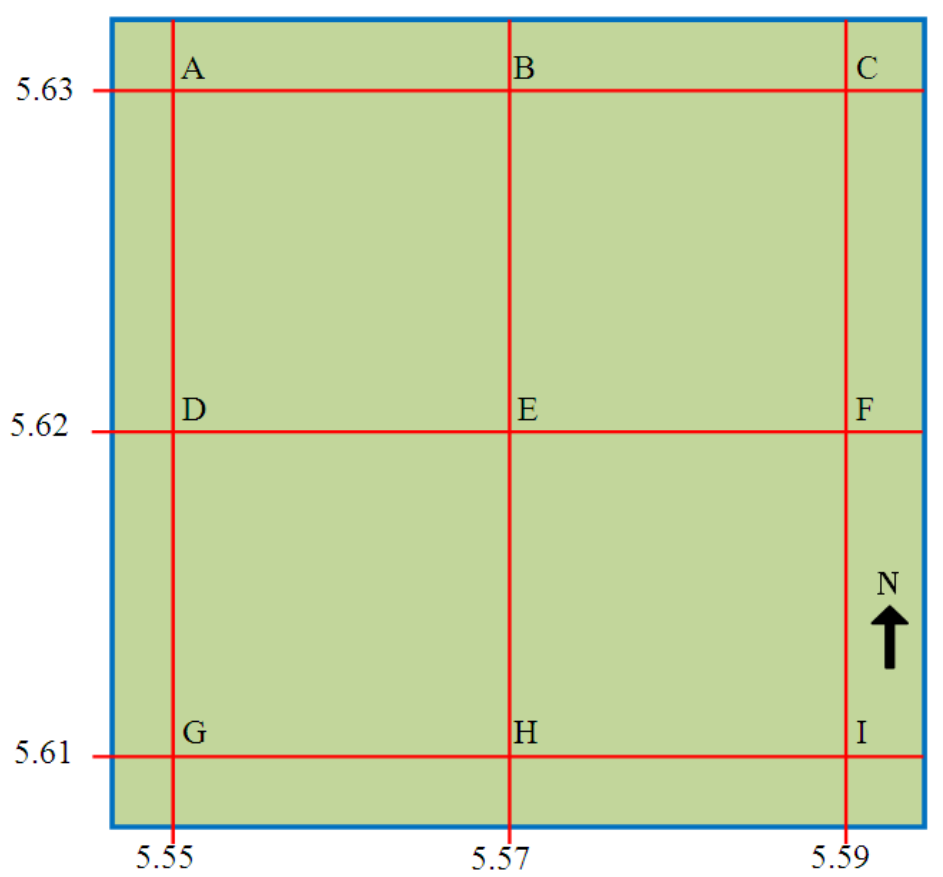

Fig. 2. Grid arrangement of the down-hole survey 


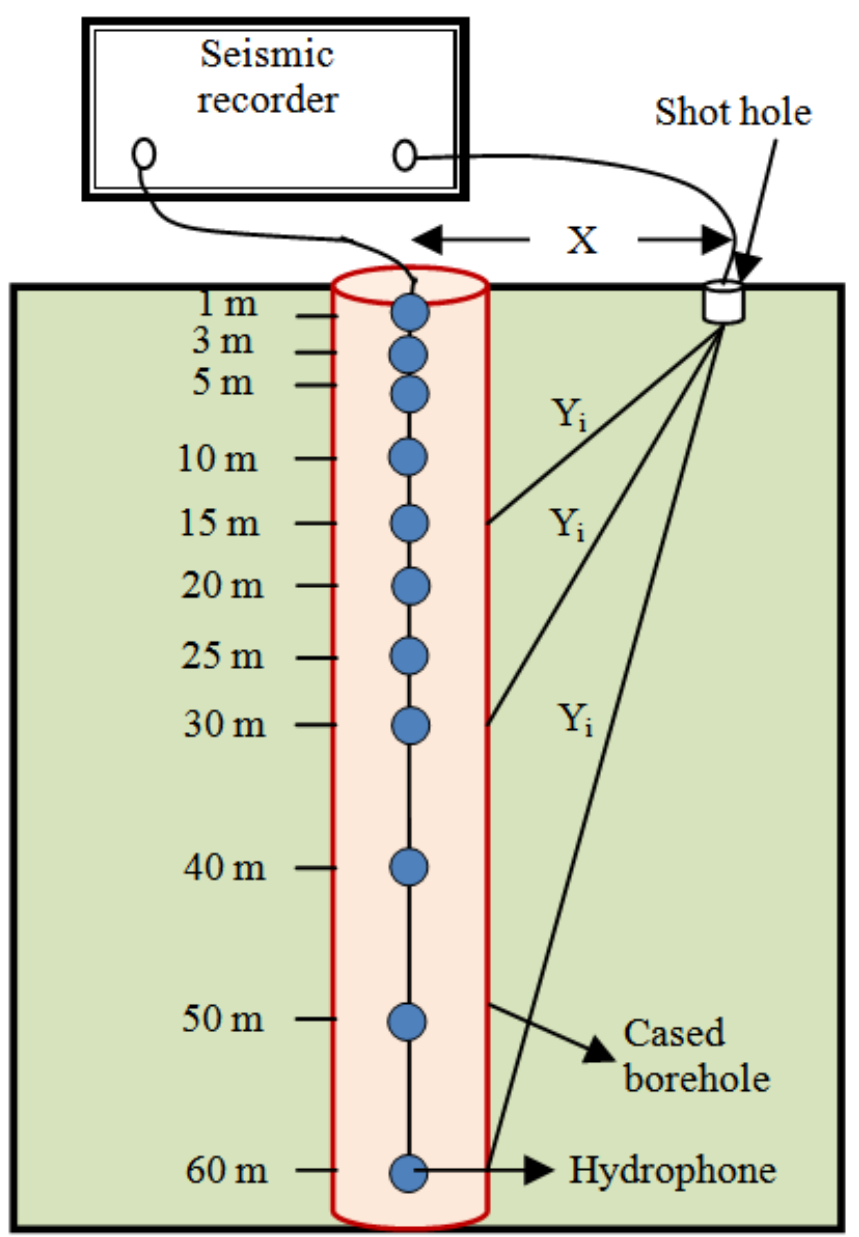

Fig. 3. Schematic diagram of downhole technique

Eleven hydrophones spread across a string at defined intervals were lowered into the boreholes to a depth of 60 metres. This was held in position by fixing a metal load at the end of the string. The hydrophones were linked with an electrical cable to the recording instrument. An offset hole of about $1 \mathrm{~m}$ deep was drilled at a distance of $5 \mathrm{~m}$ off the borehole position and loaded with $0.1 \mathrm{~kg}$ dynamite charge. The charge was detonated and the signals generated were picked up by the hydrophones in the downhole and were recorded by a McSeis-160MX recording instrument. The diagram showing the operational description of the field process is as shown in Fig. 3.

The one-way travel time was recorded at different depths in order to build up a continuous profile. The data obtained were interpreted graphically by plotting the one way travel time against the transverse distance of the seismic signal.

In determining the transverse distance travelled by the seismic signal to the hydrophone, the schematic diagram of a cased borehole as shown in Fig. 3 was considered. The transverse distance ' $\mathrm{Y}$ ' was evaluated by considering the following parameters:

- The elevation of the ground surface in contact with the energy source, $E_{S}$

- The elevation of the top of the hydrophone borehole, $\mathrm{E}_{\mathrm{H}}$

- The depth of the hydrophone to the surface $\mathrm{D}_{\mathrm{H}}$

- The horizontal distance between the energy source and the borehole, $\mathrm{X}$ 


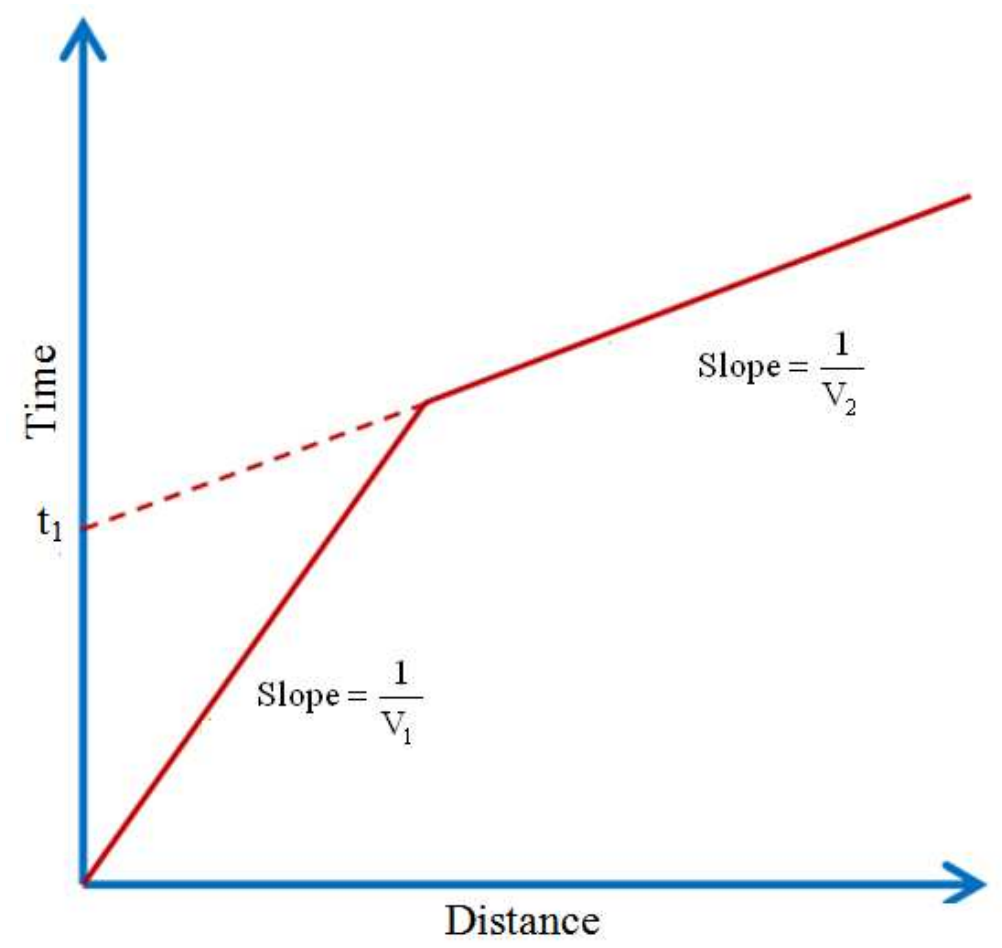

Fig. 4. Travel-Time graph for two layer surface

Hence the distance transverse by the seismic signal was obtained in this study by using the relation as expressed by Equation (1):

$$
\mathrm{Y}=\left[\left(\mathrm{E}_{\mathrm{S}}-\mathrm{E}_{\mathrm{H}}+\mathrm{D}_{\mathrm{H}}\right)^{2}+\mathrm{X}^{2}\right]^{\frac{1}{2}}
$$

Using equation 1 , the velocity of the layer can be obtained by dividing the distance ' $\mathrm{Y}$ ' by the travel time. However, in this study, the travel time was plotted against the computed transverse distance to obtain a profile from which the velocity was determined. The schematic description of a two layer time depth curve is as shown in Fig. 4. Using Fig. 4, the slope of the first straight line portion of the graph gives $1 / \mathrm{v}_{1}$ while the slope of the second portion gives $1 / v_{2}$ where $V_{1}$ is the velocity of the first layer and $V_{2}$ is the velocity of the second layer. The velocities of the various earth layers were computed from the slope which shows that the reciprocal of the slope of the lower segment of the curve equals the weathered layer velocity while that of the upper segment gives the velocity of the underlying consolidated layer.
According to Fig. 4, $t_{1}$ is the intercept of the second segment of the straight line graph. The depth to the base of the weathered layer was determined from the line intercepts $\left(\mathrm{t}_{1}\right)$ of the time axes using the relation as expressed by Equation (2) Anomohanran (2013a):

$$
\mathrm{Z}=\frac{\tau_{1} \mathrm{v}_{1} \mathrm{v}_{2}}{2 \sqrt{\mathrm{v}_{2}^{2}-\mathrm{v}_{1}^{2}}}
$$

Where:

$\mathrm{Z} \quad$ = The depth of the weathered layer

$\mathrm{V}_{1}=$ The velocity of the weathered layer

$\mathrm{V}_{2}=$ The velocity of the underlying consolidated layer and

$\mathrm{t}_{1}=$ The intercept on the graph

\section{RESULTS}

The arrival times of the first break and the hydrophone positions for all nine survey points is presented as shown in Table 1. This data was used in plotting the time-distance curves as shown in Fig. 5. 
Ochuko Anomohanran / American Journal of Applied Sciences 11 (3): 371-380, 2014
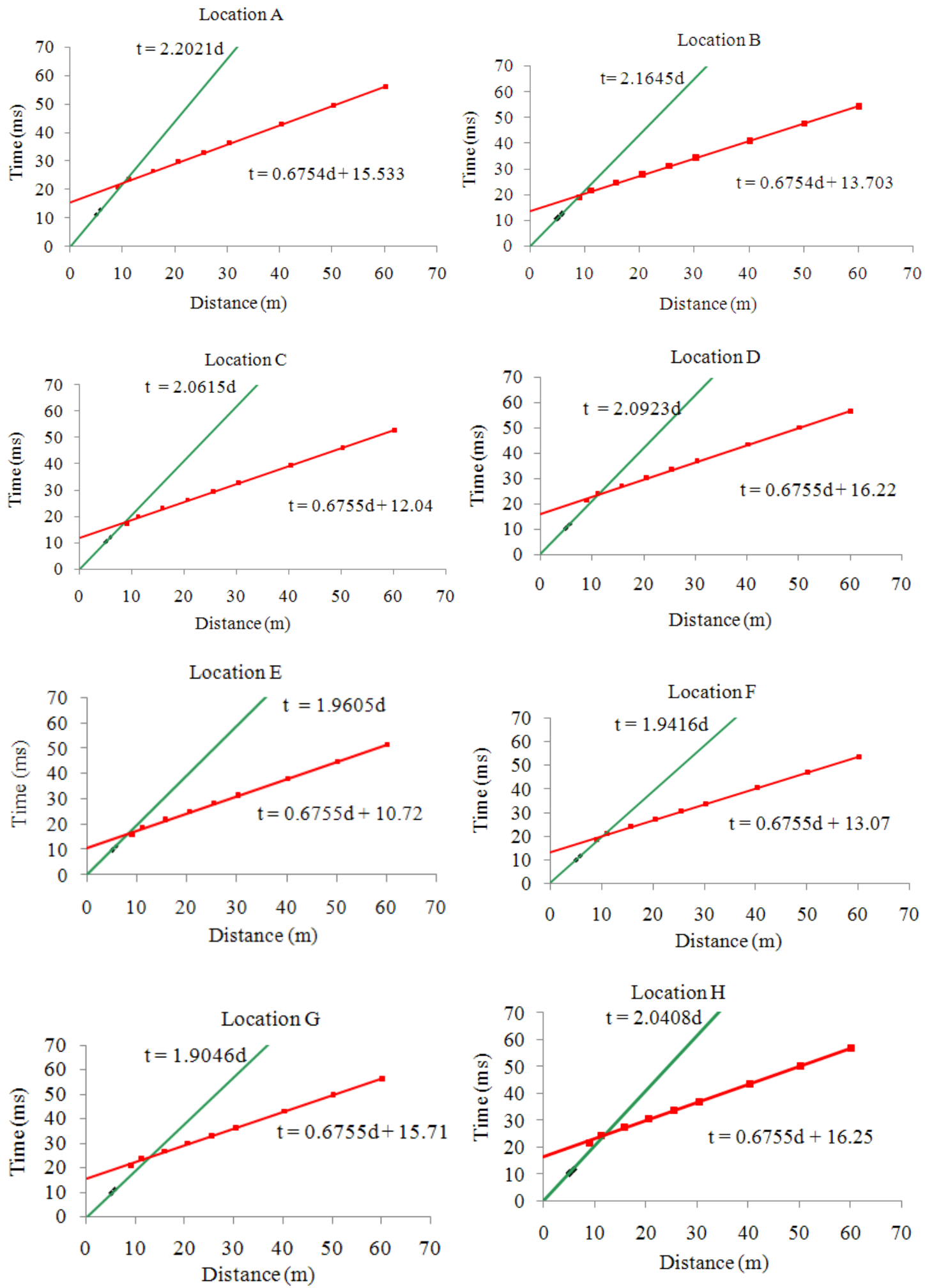

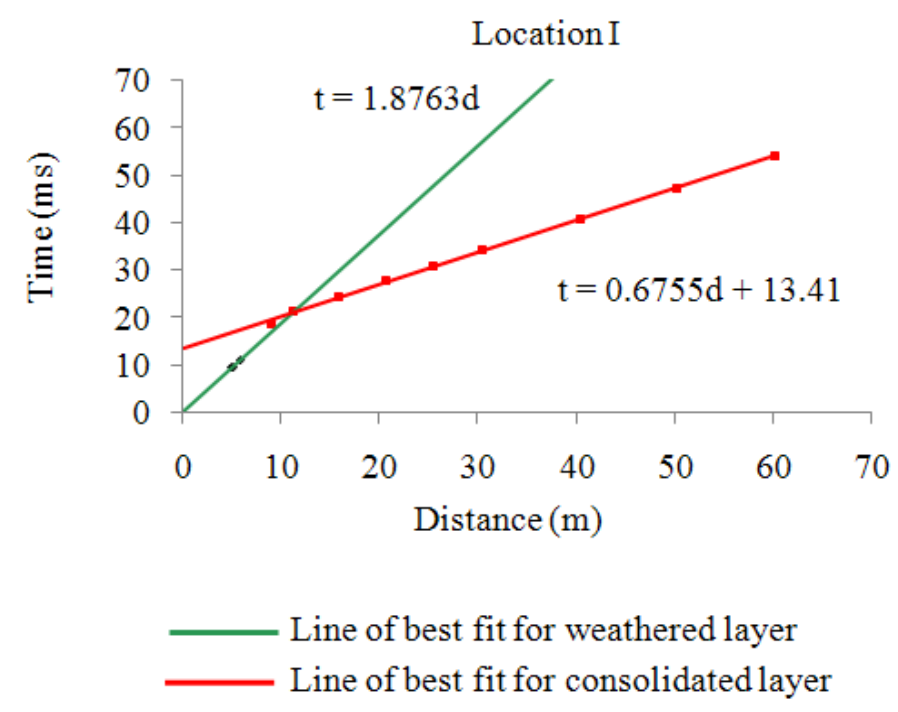

Fig. 5. Time-distance plot of the down-hole record

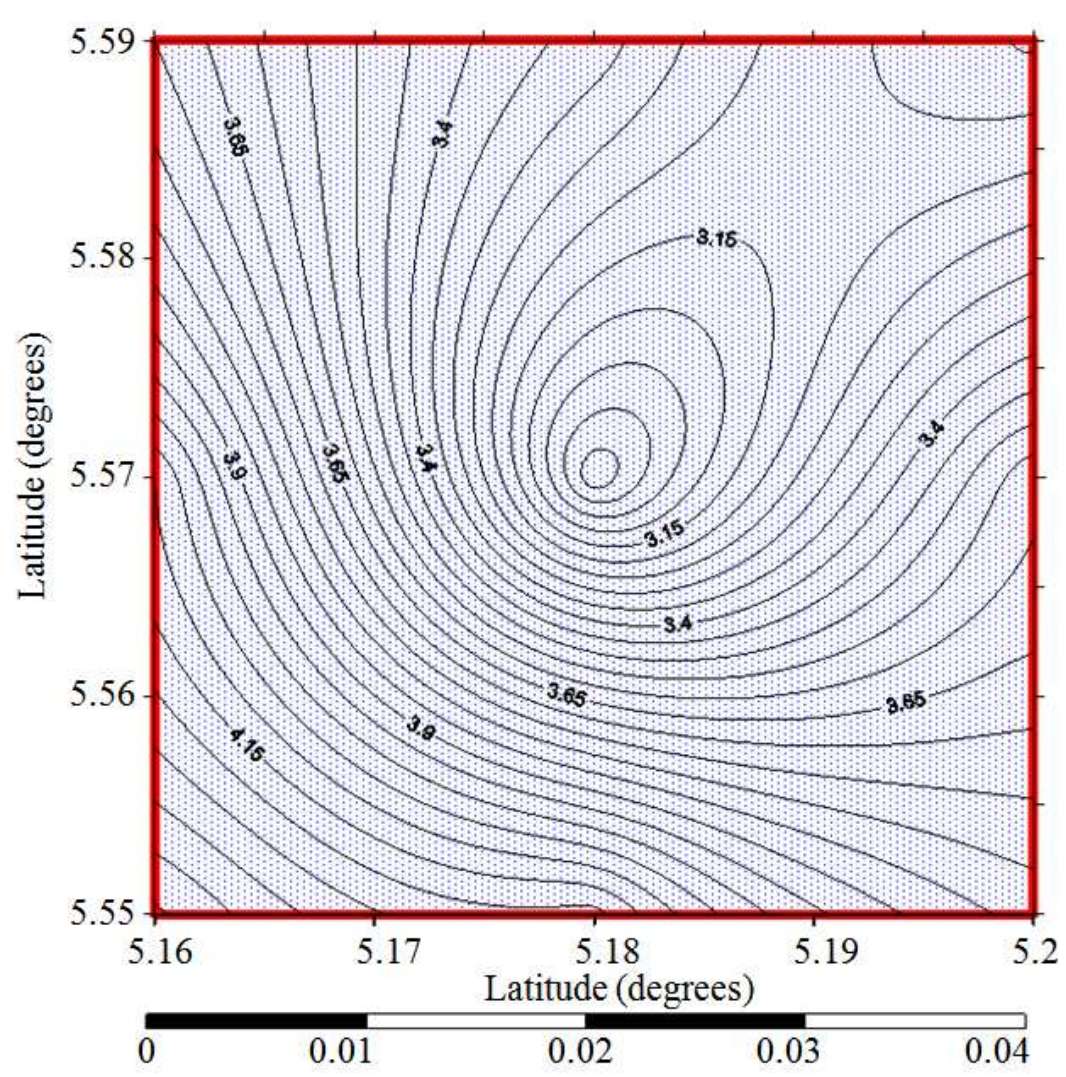

Fig. 6. Isopach map of the weathered layer (m) 
Ochuko Anomohanran / American Journal of Applied Sciences 11 (3): 371-380, 2014

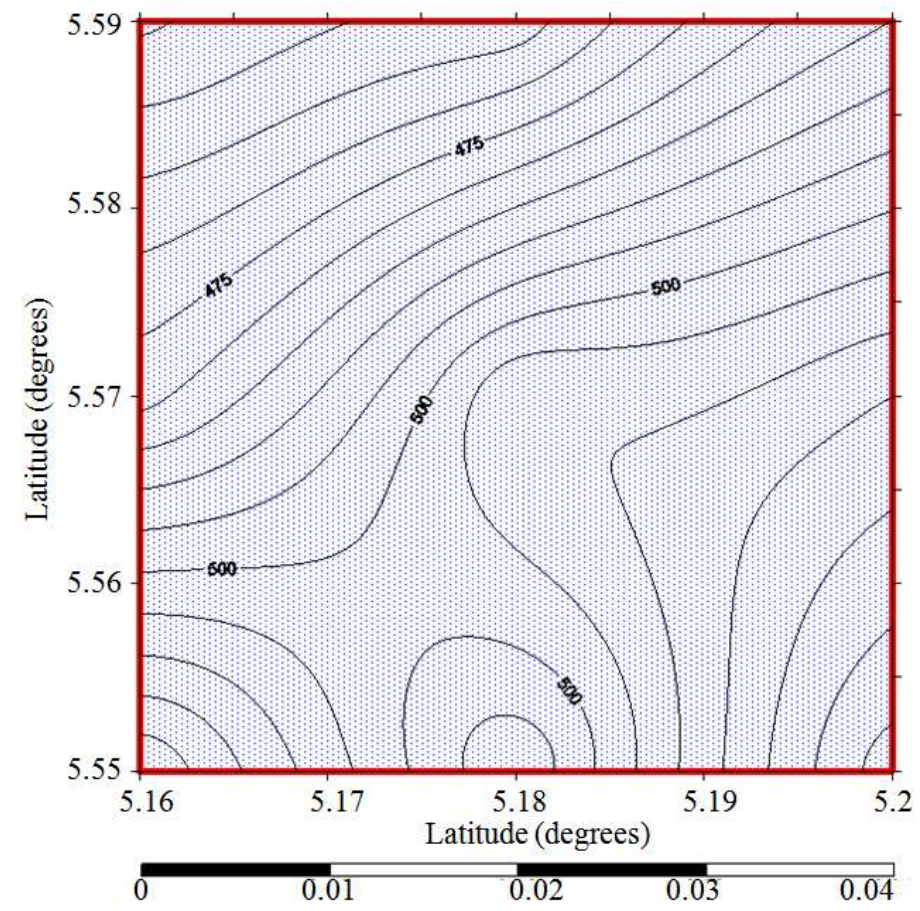

Fig. 7. Iso-velocity map of the weathered layer $\left(\mathrm{m} \mathrm{sec}^{-1}\right)$

Table 1. Data recorded from the refraction survey

\begin{tabular}{|c|c|c|c|c|c|c|c|c|c|}
\hline \multirow{2}{*}{$\begin{array}{l}\text { Receiver } \\
\text { depth (m) }\end{array}$} & \multicolumn{9}{|c|}{ Arrival time for various locations (msec) } \\
\hline & A & $\mathrm{B}$ & $\mathrm{C}$ & $\mathrm{D}$ & E & $\mathrm{F}$ & $\mathrm{G}$ & $\mathrm{H}$ & $\mathrm{I}$ \\
\hline 1 & 11.23 & 11.04 & 10.51 & 10.67 & 10.00 & 9.90 & 9.71 & 10.41 & 9.57 \\
\hline 3 & 12.84 & 12.62 & 12.02 & 12.20 & 11.43 & 11.32 & 11.11 & 11.90 & 10.94 \\
\hline 5 & 20.70 & 18.87 & 17.20 & 21.38 & 15.88 & 18.23 & 20.87 & 21.41 & 18.57 \\
\hline 10 & 23.42 & 21.59 & 19.93 & 24.11 & 18.61 & 20.96 & 23.60 & 24.14 & 21.30 \\
\hline 15 & 26.50 & 24.67 & 23.01 & 27.19 & 21.69 & 24.04 & 26.68 & 27.22 & 24.38 \\
\hline 20 & 29.70 & 27.87 & 26.21 & 30.39 & 24.89 & 27.24 & 29.88 & 30.42 & 27.58 \\
\hline 25 & 32.94 & 31.11 & 29.45 & 33.63 & 28.13 & 30.48 & 33.12 & 33.66 & 30.82 \\
\hline 30 & 36.21 & 34.38 & 32.72 & 36.90 & 31.4 & 33.75 & 36.39 & 36.93 & 34.09 \\
\hline 40 & 42.79 & 40.96 & 39.30 & 43.48 & 37.98 & 40.33 & 42.97 & 43.51 & 40.67 \\
\hline 50 & 49.40 & 47.57 & 45.91 & 50.09 & 44.59 & 46.94 & 49.58 & 50.12 & 47.28 \\
\hline 60 & 56.02 & 54.19 & 52.53 & 56.71 & 51.21 & 53.56 & 56.2 & 56.74 & 53.90 \\
\hline
\end{tabular}

Table 2. Interpreted results for the nine survey locations

\begin{tabular}{llll}
\hline DH & Thickness of weathering layer $(\mathrm{m})$ & Velocity of weathering layer $\left(\mathrm{m} \mathrm{sec}^{-1}\right)$ & Velocity of consolidated layer $\left(\mathrm{m} \mathrm{sec}^{-1}\right)$ \\
\hline A & 3.70 & 454 & 1482 \\
B & 3.33 & 462 & 1482 \\
C & 3.09 & 485 & 1480 \\
D & 4.10 & 478 & 1480 \\
E & 2.91 & 510 & 1480 \\
F & 3.59 & 515 & 1480 \\
G & 4.41 & 525 & 1480 \\
H & 4.22 & 490 & 1480 \\
I & 3.83 & 533 & 1480 \\
\hline
\end{tabular}


The intercept of the second segment of the straight line is used in estimating the thickness of the weathered layer using equation 2 and the result of the interpretation presented as Table 2. The depth profile of the weathered layer is presented as shown in Fig. 6 while the contour map showing the velocity spread for the weathered layer is presented as shown in Fig. 7.

\section{DISCUSSION}

Figure 5 shows a two layer segment and it also shows the equations of the various segments of the plots. Considering Fig. 5, the slope of the first segment of the curve was obtained as 2.2021, 2.1645, 2.0615, 2.0925, $1.9605,1.9416,1.9046,2.0408$ and 1.8763. The slope of the second segment of the curve was obtained as 0.6754 , $0.6755,0.6754,0.6755,0.6755,0.6755,0.6755,0.6755$ and 0.6755 . The slope of the lower line segment indicates the inverse of the weathered layer velocity while the slope of the second segment indicates the inverse of the consolidated layer velocity.

Table 2 shows that the velocity of the weathered layer ranged between 454 and $533 \mathrm{~m} \mathrm{sec}^{-1}$ with an average value of $495 \mathrm{~m} \mathrm{sec}^{-1}$. The study also shows that the velocity of the consolidated layer range between 1480 and $1482 \mathrm{~m} \mathrm{sec}^{-1}$. The result in Table 2 also shows that the thickness of the weathered layer ranged between 2.91 and $4.41 \mathrm{~m}$ with an average value of $3.68 \mathrm{~m}$. The range of velocities for the weathered and consolidated layers obtained in this study show similarity with the findings obtained from the study carried out in Sg.Udary, Melaka by Asry et al. (2012). Asry et al. (2012) in their work revealed that the velocities of the weathered and consolidated layers are respectively in the range of between 450 and $900 \mathrm{~m} \mathrm{sec}^{-1}$ and between 1600 and $2000 \mathrm{~m} \mathrm{sec}^{-1}$. The result in this study also agrees with the findings of the survey carried out in the Yom field in the southern Niger Delta. The study shows that the velocity of the weathered layer ranged between 250 and $800 \mathrm{~m} \mathrm{sec}^{-1}$ (Ofomola, 2011).

In a similar investigation conducted in the southeast Niger Delta, Uko et al. (2012) obtained a result which agrees with the result of this study. They obtained an average weathered layer velocity of $500 \mathrm{~m} \mathrm{sec}^{-1}$ and an average consolidated layer velocity of $1736 \mathrm{~m} \mathrm{sec}^{-1}$. In another survey carried out to investigate the properties of the weathered layer in north central Niger Delta shows a thickness which ranged from 1.3 to $3.7 \mathrm{~m}$ and a velocity range of 119 to $941 \mathrm{~m} \mathrm{sec}^{-1}$ (Alaminiokuma and
Amonieah, 2012). This shows that the thickness and velocity of the weathered layer obtained in the current study, falls within the range obtained by Alaminiokuma and Amonieah (2012).

Figure 6 shows that the depth of the weathered layer deepens southeastward while Fig. 7 shows that the velocity also increases southeastward. These results shown in Fig. 6 and 7 are very useful parameters in engineering construction and soil evaluation in the area which is characterised by industrial and infrastructural growth. It is recommended that construction of heavy buildings and road infrastructures especially bridges in the study area should have their foundations laid to a depth of $4.41 \mathrm{~m}$ to enable the infrastructure sit on the consolidated layer. It is also recommended that shots for seismic survey in the study area should be located at a depth of $4.41 \mathrm{~m}$ to eliminate the effects associated with the low velocity layer.

\section{CONCLUSION}

This study carried out to investigate the velocity and depth of the weathered layer using a downhole seismic refraction technique has been carried out in Escravos, Nigeria. A total of nine stations was covered and results showed that the weathered layer thickness in the area ranged between 2.91 and $4.41 \mathrm{~m}$ with an average weathered layer depth of $3.68 \mathrm{~m}$. The study also revealed that the weathered layer velocity in the area ranged between 454 and $533 \mathrm{~m} \mathrm{sec}^{-1}$ with an average value of $495 \mathrm{~m}$.

The weathered layer parameters obtained from this study are very useful in analysing the soil behaviour under static and dynamic loads and are helpful to civil engineers working in the area. Nevertheless, the study could not draw up a relationship between downhole seismic refraction and surface seismic refraction to arrive at a more conclusive analysis. This is the reason why in the future, an uphole seismic refraction survey which has the advantage of recognizing thin and hidden beds should be carried out to draw conclusions on the weathered layer properties.

\section{REFERENCES}

Abdul-Nafiu, A.K., M.N.M. Nordin, K. Abdullah, I.K. Saheed and A. Abdullah, 2013. Effects of electrode spacing and inversion techniques on the efficacy of 2D resistivity imaging to delineate subsurface features. Am. J. Applied Sci., 10: 64-72. DOI: 10.3844/ajassp.2013.64.72 
Alaminiokuma, G.I. and J. Amonieah, 2012. NearSurface structural model for enhanced seismic data acquisition and processing in north-central Niger Delta. Am. J. Sci. Indus. Res., 3: 252-262. DOI: 10.5251/ajsir.2012.3.5.252.262

Akpoborie, I.A., B. Nfor, A.A.I. Etobro and S. Odagwe, 2011. Aspects of the geology and groundwater condition of Asaba Nigeria. Arch. Applied Sci. Res., 3: 537-550.

Anomohanran, O., 2012. Geophysical interpretation of seismic reflection data obtained from the Umureute and Amiynaibo area of Delta State, Nigeria. Nigerian J. Sci. Environ., 11: 148-154.

Anomohanran, O., 2013a. Seismic refraction method: A technique for determining the thickness of stratified substratum. Am. J. Applied Sci., 10: 853-862. DOI: 10.3844/ajassp.2013.857.862

Anomohanran, O., 2013b. Evaluation of aquifer characteristics in Echi, Delta State, Nigeria using well logging and pumping test method. Am. J. Applied Sci., 10: 1263-1269. DOI: 10.3844/ajassp.2013.1263.1269

Anomohanran, O., 2013c. Geophysical investigation of groundwater potential in Ukelegbe, Nigeria. J. Applied Sci., 13: 119-125. DOI: 10.3923/jas.2013.119.125

Asry, Z., A.R. Samsudin, W.Z. Yaacob and J. Yaakub, 2012. Geoelectrical resistivity imaging and refraction seismic investigations at Sg.Udang, Melaka. Am. J. Eng. Applied Sci., 5: 93-97. DOI: 10.3844/ajeassp.2012.93.97

Ayolabi, E.A., L. Adeoti, N.A. Oshinlaja, I.O. Adeosun and O.I. Idowu, 2009. Seismic refraction and resistivity studies of part of Igbogbo township, south-west Nigeria. J. Scientif. Res. Dev., 11: 42-61.

Chiemeke, C.E. and H.O. Aboh, 2012. Delineation of aquiferous layers within the basement complex using joint inversion of seismic refraction tomography and high resolution 3D seismic reflection survey. Arch. Applied Sci. Res., 4: 400405 .
Gabr, A., H. Murad, H. Baker, K. Bloushi and H. Arman et al., 2012. The use of seismic refraction and electrical techniques to investigate groundwater aquifer, Wadi Al-ain, United Arab Emirates (UAE). Proceedings of the International Conference on Water Resources and Wetlands, Sept. 14-16, Tulcea-Romania, pp: 94-99.

Igboekwe, M.U. and H.E. Ohaegbuchu, 2011. Investigation into the weathering layer using up-hole method of seismic refraction. J. Geological Mineral Res., 3: 73-86.

Kar, S.Z. and A. Berenjian, 2013. Soil formation by ecological factors: Critical review. Am. J. Agric. Biol. Sci., 8: 114-116. DOI: 10.3844/ajabssp.2013.114.116

Kolawole, F., C. Okoro and O.P. Olaleye, 2012. Downhole refraction survey in Niger Delta basin: A 3-layer model. ARPN J. Earth Sci., 1: 67-79.

Ofomola, M.O., 2011. Uphole Seismic refraction survey for low velocity layer determination over Yom field, South east Niger delta. J. Eng. Applied Sci., 6: 231-236. DOI: 10.3923/jeasci.2011.231.236

Teachavorasinskun, S., P. Pattararattanakul and P. Pongvithayapranu, 2009. Liquefaction Susceptibility in the Northern Provinces of Thailand. Am. J. Eng. Applied Sci., 2: 194-201. DOI: 10.3844/ajeassp.2009.194.201

Uko, E.D., I. Tamunobereton-Ari and V.B. OmuboPepple, 2012. Comparison of compressional wave velocity-depth profiles from the surface and downhole detectors in the near surface in the southeast Niger Delta, Nigeria. Int. J. Asian Social Sci., 2: 869-880.

Varughese, A. P. Kumar and N. Kumar, 2011. Seismic refraction survey a reliable tool for subsurface characterisation for hydropower projects. Proceedings of the Indian Geotechnical Conference, Dec. 15-17, Kochi, pp: 137-139. 